\title{
Testing the Pecking Order Theory of Internal Funding Deficit: Evidence from Indonesian Sub-Sector Property and Real Estate
}

\author{
Arief Seantero Budiman ${ }^{1}$, Tony Irawan $^{2}$, Lukytawati Anggraeni ${ }^{3}$ \\ ${ }^{1,2,3}$ Bogor Agricultural University, School of Business, J1 Raya Pajajaran, Bogor, Indonesia
}

\begin{abstract}
Property and real estate subsectors in Indonesia are part of the cause to economic augmentation, but in the recent years its escalation has been slowing. Property and real estate fit in a capital-intensive sub-sector, as well as companies requiring huge external capital. External financing is also faced with the risk that the company should be held accountable to those external parties. The objective of this research is to analyze the company's capital structure in the property and real estate sub-sector through testing the pecking order theory. The results of the analysis reveals that the internal funding deficit has a significant positive impact on long-term corporate debt changes in the agricultural sector listed on the BEI. This presents that in determining the company's capital structure policy, companies in property and real estate sub-sector listed on BEI have employed pecking order theory concept.
\end{abstract}

Keywords: Property, real estate, capital structure, pecking order theory

\section{Introduction}

Indonesia's population enlargement continues to increase, indicating that property and real estate industries will expand as well. Moreover, property and real estate sectors give to economic growth in Indonesia too. However, in the last few quarters the increases in supply and demand of commercial property and real estate in Indonesia has been delayed [1].

Property and real estate sub-sector is a capital intensive subsector, where capital is apportioned as a fund in the process of purchasing land and construction, as well as companies requiring great capital from external parties. Nevertheless, external financing also stands facing with the risk that the company should be held accountable to those external parties. Thus, it is necessary for consideration for the management for the most appropriate capital structure for property companies and real estate.

Capital structure is very essential in decision making financing the company's operational activities. The enormity of this capital structure depends on the composition of the company's funding sources both internally as well as from external companies. The trade off theory explains if you desire to get huge revenue, then the debt is in big responsibility (Sudana 2011) [2]. While the pecking order theory is a systematic alternative funding company, and the use of less debt to enlarge corporate profits.

Therefore, the purpose of this research is to analyze the capital structure used in the property and real estate subsector companies listed on the Indonesia Stock Exchange.

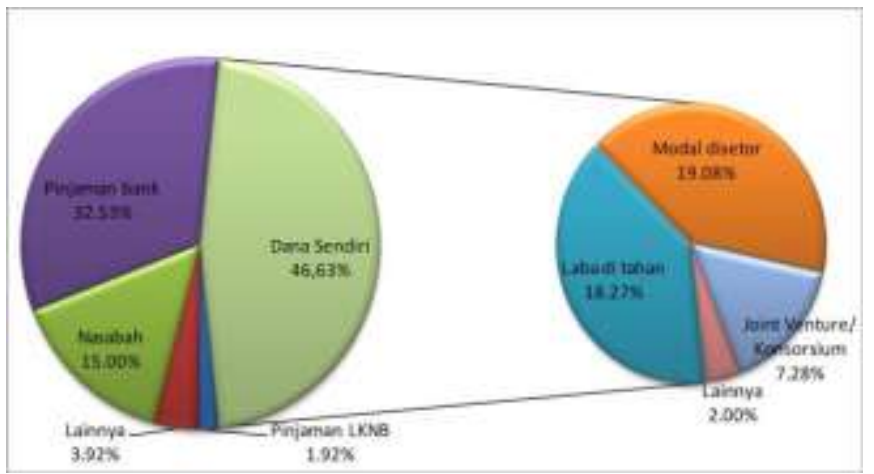

Figure 1: Current capital structure firms in sub-sector property and real estate

\section{Literature Review}

The capital structure is a combination of debt and equity use as a long-term financing of the company [3]. The capital structure can be defined as a source of companies funding derived from debt and stocks to finance an investment, corporate operations and corporate growth in the future [4].

The Pecking Order Theory explains that companies should consider when deciding the funds use preferences starting from the cheapest funding [5]. The company will firstly use the funds sources derive from the internal of the company (retained earnings), when the capital needs increase, the company will secondly use external debt financing, and finally the company will use internal funds namely equity when the debt is not sufficient to meet the capital requirement. However, according to trade-off theory is that the starting point of a review of the firm's capital structure decision is on the debt-target ratio where tax protection of debt is maximized and the cost of bankruptcy related to debt is minimized [4]. Predicts optimal capital structure will not be achieved by the company, but the company will use external funding when the debt capacity is achieved by following certain principles [8]

Volume 6 Issue 12, December 2017

www.ijsr.net 


\section{International Journal of Science and Research (IJSR) \\ ISSN (Online): 2319-7064}

Index Copernicus Value (2016): 79.57 | Impact Factor (2015): 6.391

\section{Methods}

\subsection{Type and Sources of Data}

The type of data used in this research is secondary data. Source of data derived from the financial statements of 15 issuers property and real estate sub-sector during 2010-2015 period, consisting of balance sheet, cash flow statement, statement of changes in equity, profit / loss statement, and notes to the financial statements. The data is obtained by downloading Indonesia Stock Exchange website (www.idx.co.id), related company website, and also other information that can support this research.

\subsection{Anlisis Data}

Data analysis method used to answer packing-order theory test in property sub sector company and real estate is regression analysis method of panel data. This analysis instrument is used based on the suitability of the data used that involves cross-section and time series data.

For testing the theory of packing-order on the capital structure is used as follows:

$$
\begin{aligned}
& \triangle L T D i t=\alpha_{0}+\alpha_{1} \text { DEFit }+\varepsilon_{1} \\
& \text { Informayion: } \\
& \Delta L T D i t=\text { Amount of debt change in the long-term debt } \\
& \text { (long-term debt) of issuer } i \text { in year } t \\
& \text { DEFit =internal funding deficit of issuer to } \mathrm{i} \text { in year } \mathrm{t} \\
& \alpha_{0} \quad=\text { constants } / \text { intercept }
\end{aligned}
$$

$$
\begin{aligned}
& \alpha_{1}=\text { regression coefficient which is the coefficient of } \\
& \text { pecking order theory } \\
& \varepsilon_{1}=\text { Error term }
\end{aligned}
$$

\section{Descriptive Analysis}

The object of the research is sub-sector companies property and real estate listed on the Indonesia Stock Exchange since January 2010 until December 2015. Based on above criteria, it is obtained 15 companies during six periods of the bookkeeping year. Testing of pecking order theory in this research is done through regression.

The long term debt change in this research is used as the dependent variable to prove the existence of pecking order theory on the issuer of property and real estate sub-sector listed in Indonesia Stock Exchange. Changes of long term debt can be seen in Table 8 . The long-term debt value of several publicly-listed property and real estate issuers shows fluctuation. In general, most issuers in the property and real estate sub-sector show positive debt changes. However, there are some emitters that point to negative debt growth trends including JRPT, LAMI, and SMDM. In general, LPKR

\begin{tabular}{|c|c|c|c|c|c|c|c|c|c|c|}
\hline \multirow{2}{*}{ No } & \multirow{2}{*}{ niten } & \multicolumn{6}{|c|}{ Tahun } & \multirow{2}{*}{ Iin } & \multirow{2}{*}{ Iax } & \multirow{2}{*}{ ata-rata } \\
\hline & & 10 & 11 & 2012 & 2 & 4 & 2015 & & & \\
\hline 1 & 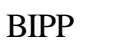 & & & $5 / 0$ & & & & & & 301 \\
\hline 2 & $V_{r}$ & 183 & 15 & 12799 & 1644937 & -1092737 & 132503 & -1092737 & 164493 & 8411 \\
\hline 3 & $\mathrm{CTF}$ & 404 & & 20356 & 309 & 417 & & & & \\
\hline 4 & $\mathrm{DA}$ & ) & 5 & 9 & 10 & 3 & 9 & & & 229755 \\
\hline 5 & DUTI & -26072 & 151040 & 316533 & -774294 & 310460 & 163276 & -7742 & & 0157 \\
\hline 6 & ent & 0033 & & 16 & 205154 & -68187 & -140225 & & & 21 \\
\hline 7 & JRPT & 566889 & -1116951 & 81996 & 6090 & 19450 & 27721 & -1116951 & & -69134 \\
\hline 8 & KIJA & 2488 & 479356 & 747738 & 424032 & 504854 & 894367 & 42 & & 473 \\
\hline 9 & & 589 & & 00 & & 15J0 & & & & -56304 \\
\hline 10 & LP & 200200 & 3145 & -62475 & -146 & 27012 & 59 & -3 & & 4533 \\
\hline 11 & & 2182206 & 1521265 & 3323920 & 2361244 & 2108154 & 3163531 & 1521265 & 332 & 2443387 \\
\hline 12 & ML & 154933 & 63528 & 496903 & 1689957 & 878243 & 226468 & 63528 & 957 & 585005 \\
\hline 13 & & -15215 & 254220 & 291498 & -67127 & 2228655 & 324864 & -67127 & 2228655 & 502816 \\
\hline 14 & SM & -344538 & 166917 & 73382 & -171874 & 8201 & -113425 & -344538 & 166917 & -45223 \\
\hline 15 & SMRA & 151734 & 475213 & -186150 & 2100010 & 1430738 & 1424581 & -186150 & 2100010 & 899354 \\
\hline
\end{tabular}
shows the highest value of long term debt change compared to other issuers and always shows positive debt growth. Besides, SMRA is on the second place of its debts growth changes with an average growth rate of Rp 899395 million over the past six years. As for the details of long term debt developments in 15 listed property and real estate sub-sector over the last six years are available in Table 1.

Table 1: Changes in long term debt issuers of property and real estate subsectors in 2010- 2013 (in millions of rupiah)

(+) Debt increases, (-) Debt decreases

Internal funding deficits are factors that affect companies to use external funding sources. The internal funding decisions indicate that the cash position earned from the company's operations is not sufficient to finance the company's future activities. Internal funding deficit is measured from dividend payments, investment payments, changes in working capital, minused by the net income of the company [6]. In this research, the internal funding deficit is used as an independent variable to prove the existence of pecking order theory in the property and real estate sub-sector listed on the

\section{Volume 6 Issue 12, December 2017}




\section{International Journal of Science and Research (IJSR) \\ ISSN (Online): 2319-7064}

Index Copernicus Value (2016): 79.57 | Impact Factor (2015): 6.391

BEI. Changes in internal funding deficits can be seen in Table 2. LPKR shows the highest funding deficit value with a value reaching Rp 4765571 million, this is what motivated LPKR to increase its debt level where its debt growth rate also showed the highest value compared to other issuers.
Then, the other highest funding deficit value is DUTI with Rp 2894322 million, but the value of its debt growth is not in line with the high fund deficit amount.

Table 2: Internal funding deficits of agricultural sector issuers in 2010-2013 (in millions of rupiah)

\begin{tabular}{|c|c|c|c|c|c|c|c|c|c|c|}
\hline \multirow{2}{*}{ No } & \multirow{2}{*}{ Emiten } & \multicolumn{6}{|c|}{ Tahun } & & & \multirow{2}{*}{ ata-rata } \\
\hline & & 10 & 011 & 2012 & 2013 & 4 & 2015 & & & \\
\hline 1 & & & & & & & & & & \\
\hline 2 & KSI & 7 & 6 & 49 & 767 & 95 & 282 & -3 & & 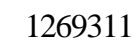 \\
\hline 3 & CII & 000 & 19319 & -1950792 & 445102 & 932660 & 909 & & & 9530 \\
\hline 4 & -1 & II & 2972 & 343 & -31996 & & 30 & & & \\
\hline 5 & (11 & 2095824 & 503093 & 4906750 & 1726279 & 2478642 & 36 & & & 322 \\
\hline 6 & 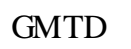 & 925 & -42217 & 116 & 41705 & 5235 & 72 & & 5 & 34 \\
\hline 7 & JW & 589910 & 0698 & 531 & -578191 & 715675 & 755 & & & 932 \\
\hline 8 & KIJA & 668316 & 2226323 & 285295 & 144162 & 299441 & -174560 & -174 & & 1829 \\
\hline 9 & the & -603149 & -190007 & T & 0001 & $20+02$ & 155769 & & & (2) \\
\hline 10 & LPC & 906 & -126609 & 431551 & 333269 & 924500 & 1073044 & 6 & 44 & 308 \\
\hline 11 & LP & 1503522 & 1966959 & 360 & 42 & 5532654 & 509 & & & \\
\hline 12 & $\mathrm{~N}$ & & 4 & 15 & -64 & 9 & 30 & & & \\
\hline 13 & PWON & 349942 & 935150 & 359693 & 338672 & 2791379 & -358353 & & & 736081 \\
\hline 14 & SMDM & 1830436 & -1168121 & 1036831 & 196645 & 453703 & 618791 & -1168121 & 1830436 & 494714 \\
\hline 15 & SMRA & 799430 & 666164 & 643473 & 696721 & 492389 & 2232348 & 492389 & 2232348 & 921754 \\
\hline
\end{tabular}

(-) DEF Surplus, (+) DEF Deficit

The internal funding deficit average of property and real estate sub-sector companies is in line with rising long-term debt. This is an early indication that there is a positive relationship between internal funding deficits and long-term debt in issuers, engaged in property and real estate subsectors. The value development of LTD and DEF is available in Figure 1.

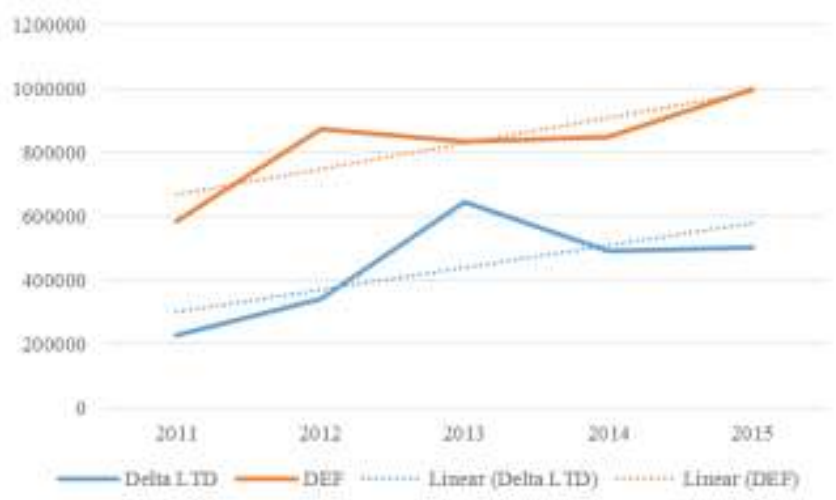

Figure 2: DEF and LTD value developments in property and real estate sub sector in the year of 2011-

\section{Result}

Regression analysis, which was used as an evidence of pecking order theory concept, used internal funding deficit as independent variable and long term debt change as dependent variable so that result of analysis based on Random Effect Model method is explained in Table 3.
Table 3: Regression analysis results of Pecking Order Theory panel test data

\begin{tabular}{|c|c|c|c|c|}
\hline Variable & Coefficient & Std. Error & $t$-Statistic & Prob. \\
\hline C & $1.99 \mathrm{E}+11$ & $1.36 \mathrm{E}+11$ & 1.462850 & 0.1478 \\
\hline DEF & 0.294125 & 0.046281 & 6.355261 & 0.0000 \\
\hline
\end{tabular}

Based on table 3, it can be seen that the internal funding deficit (DEF) has a probability of less than alpha (0.05) with a coefficient of 0.294125 . This means that internal funding deficits have a significant positive effect on long term debt changes. The selection of the best model in panel data regression is conducted by using Chow test and Hausman test. Chow test is a testing method to choose whether the model approach used is pooled least square (PLS) or fixed effect method (FEM), while Hausman test is a test method to choose whether the model used is random effect model (REM) or fixed effect method (FEM). If based on the selected Chow test is pooled least square (PLS), then Hausman test is not necessarily done. The hypothesis used in the Chow test is as follows:

H0: Model pooled least square

H1: Model fixed effect

The rejection criterion used in the Chow test is, reject H0 if the value of $\mathrm{P}$-value <alpha value $(\alpha=0.05)$. The Chow test in this study used the eviews program, where the test results showed that the probability value of cross section $\mathrm{F}(0.0000)$ is smaller than the alpha value $(\alpha=0.05)$, so the null hypothesis (H0) is rejected, which means that for the temporary best model to analyze Panel data regression is using fixed effect model (FEM) method (Tabel 4). 


\section{International Journal of Science and Research (IJSR) \\ ISSN (Online): 2319-7064}

Index Copernicus Value (2016): 79.57 | Impact Factor (2015): 6.391

Table 4: Analysis Results of Chow Test

\begin{tabular}{|l|c|c|c|}
\hline \multicolumn{1}{|c|}{ Effect Test } & Statistic & d.f. & Prob. \\
\hline Cross-section F & 5.144834 & $(14,59)$ & 0.0000 \\
\hline Cross-section Chi-square & 59.840338 & 14 & 0.0000 \\
\hline
\end{tabular}

Furthermore, is done a testing to select the model of random effect or fixed effect with Hausman test method. The hypothesis used in the Chow test is as follows:

H0: Model random effect

H1: Model fixed effect

The rejection criterion which is used in the Hausman test is, it will reject $\mathrm{H} 0$ if the value of $\mathrm{P}$-value $<$ alpha value $(\alpha=$ 0.05). The Hausman test indicates that the value of probability cross section $F(0.4149)$ is higher than the alpha value $(\alpha=0.05)$, so that the null hypothesis (H0) is rejected, which means that the best model to analyze panel data regression is using random effect model (REM).
Table 5: Analysis Results of Hausman Test

\begin{tabular}{|c|c|c|c|}
\hline Test Summary & $\begin{array}{c}\text { Chi-Sq } \\
\text { Statistic }\end{array}$ & $\begin{array}{c}\text { Chi- } \\
\text { Sq.d.f. }\end{array}$ & Prob. \\
\hline Cross-section random & 0.664603 & 1 & 0.664603 \\
\hline
\end{tabular}

The test of classical assumption is conducted in order the regression analysis results could be BLUE (best linier unbiased estimators). The classical assumption tests cover autocorrelation test, heteroscedicity test, and normality test. Based on the result of panel data regression analysis where the best model is chosen, is Random effect model (REM). The benefit of this model is violation of heteroskedasitas and autocorrelation has been truly corrected. As for the other classical assumption test is the normality test. The normality test is implemented to determine whether the data has been normally distributed or not. The result of normality test is presented in Figure 2.

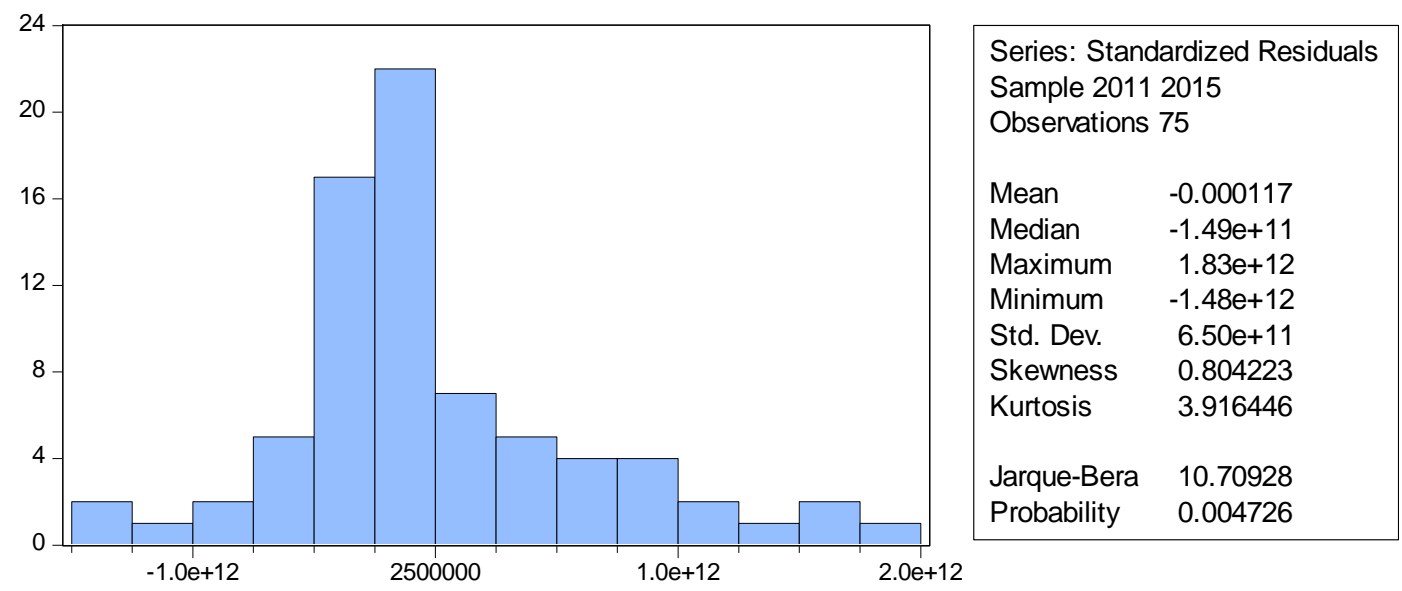

Figure 3: The result of Normality test

Based on above Figure 2, the Jarque-Bera value is getting 10.70928, that is smaller than the Chi-Square value of 95.08, so that it can be concluded that the residual data is normally distributed. Based on the descriptive statistical value by using the random effect model (REM) in Table 13, it can be seen that the independent variable (internal funding deficit) gets a positive effect on long term debt change significantly. This can be checked from the probability value of t-statistics (0.0000) which is less than the alpha value (5\%). The regression equation in the regression analysis of the proof of pecking order theory is as follows:

\section{$\Delta \mathrm{LTDit}=1.99 \mathrm{E}+11+0.294125$ DEFit}

Based on the former Table 6 , it is found out that the value of $\mathrm{R} 2$ is 0.3572 . It indicates that the diversity of internal funding defisit independent variable which is used, could explain the diversity of dependent variables in the model of $35.72 \%$ and the rest of it is $64.28 \%$ which is explained by the diversity of other independent variables outside the model. $\mathrm{F}$ test results to investigate the effect of independent variables on the dependent variable states the value of 40.5757 with a probability value around 0.000 which is smaller than alpha $(\alpha$ $=5 \%$ ). From the test results, it can be interpreted that the independent variable affects the dependent variable significantly. Meanwhile, t-statistic test result on DEF variable indicates the value of 6.3552 with probability value 0.0000 which is smaller than alpha $(\alpha=5 \%)$. This concludes that the initernal funding deficit (DEF) brings positive effects significantly to long-term debt change (Delta LTD) at 5\% real level. This corresponds to the former hypothesis of this study which states that internal funding deficit gives positive influence to long term debt changes.

Table 6: The Result of Regression Analysis Using Random Effect Model (REM) Method

\begin{tabular}{|c|c|c|c|}
\hline Variabel & Koefisien & t-statistik & Probabilitas \\
\hline C & $1.99 \mathrm{E}+11$ & 1.462850 & 0.1478 \\
\hline DEF & 0.294125 & 6.355261 & \\
\hline R-squared & 0.357257 & & \\
\hline Adjusted R- squared & 0.348453 & & \\
\hline F-statistic & 40.57576 & & \\
\hline Prob(F-statistic) & 0.000000 & & \\
\hline
\end{tabular}

The results of this research analysis demonstrates that the company has pursued the systematic pecking order theory explicitly employing the source of corporate financing from the cut-rate source of financial support. The management side of the issuers in the agricultural sector is recommended to ensue the pecking order theory rule to be exact by using the external financial support hierarchy from the inexpensive resource and keep maintaining the maximum debt level to

\section{Volume 6 Issue 12, December 2017}




\section{International Journal of Science and Research (IJSR) \\ ISSN (Online): 2319-7064}

Index Copernicus Value (2016): 79.57 | Impact Factor (2015): 6.391

lessen the average capital cost. However, the corporate also wants to deem that if the source of debt financing has gone beyond the equity / asset so that it will come into sight high monetary pressure (financial distress) in the upcoming time. This is because the greater the burden of principal and interest on the debt the company should pay, the more likely it is that the company is coming across the financial inconvenience leading to bankruptcy or non-payment.

\subsection{Managerial Implication}

The above result of research analysis indicates that the company has gone behind the systematic pecking order theory that is exploiting the source of corporate financing from the lowest-cost basis of funding. The management of the issuers in the agricultural sector is recommended to go after the pecking order theory principle by using the hierarchy of external funding from the inexpensive source and keep the highest debt level to diminish the average capital cost. However, the company also needs to regard as that if the source of debt financing has exceeded equity / asset then it will emerge high financial force (financial distress) in the future. This is because the greater the weight of principal and interest on the debt the company pays, the more likely it is that the company is going through financial complexities directing to economic failure or default.

\section{Conclusion}

The previous results of the analysis on the proof of pecking order theory concept using regression analysis illustrates that the internal funding deficit has a significant positive effect to the alteration of long-term debt of firms in agriculture sector listed on the BEI. This confirms that in determining the company's capital structure policy, companies in the property and real estate sub-sector listed on the BEI have employed the concept of pecking order theory.

The findings indicate that the pecking order theory is an excellent descriptor for deficit firms, but a poor one for surplus firms [7].

\section{References}

[1] Bank Indonesia. 2016. Resindential Property Survey supply. 2016. Jakarta (ID): Bank Indonesia

[2] Sudana, I. 2011. Manajemen Keuangan Perusahaan Teori dan Praktek. Jakarta (ID) : Erlangga

[3] Brigham EF dan Houston JF. 2004. Fundamentals of Financial Management. Ed ke-10. Ohio (US): SouthWestern.

[4] Berk J dan Peter DM. 2011. Corporate finance the core. Ed ke-2. New york (US): Pearson Education.

[5] Myers S dan Majluf N. 1984. Corporate financing decisions when firms have information investors do not have. Journal of Financial Economics. 13: 187-221.

[6] Frank MZ dan Goyal KV. 2003. Testing the packing order theory of capital structure. Journal of financial economics. 67: 217-248.

[7] Bhama V, Jain PK and Yadav SS. 2016. Testing the pecking order theory of deficit and surplus firms: indian evidence. International Journal of Managerial Finance. 12: 335-350.

[8] Jahanzeb A, Rahman SU, Bajuri NH, Karami M, Ahmadimousaabad A. 2013.Trade-Off theory, pecking order theory and market timing theory: A comprehensive review of capital structure theories. International Journal of Management and Commerce Innovations. 1(1):11-18.

\section{Author Profile}

Arief Seantero Budiman received the bachelor degree in Management, Faculty of Management, University of Bengkulu in 2013. He continued his study in Management and Business, School of Business at Bogor Agricultural University from 2015.

Volume 6 Issue 12, December 2017 